\title{
Pamukta Lif Uzamasıyla İlişkili Genlerin Polimorfizmi
}

\author{
Gülay Zülkadir ${ }^{1, *}$, Yüksel Bölek ${ }^{2}$ \\ ${ }^{I}$ Tarla Bitkileri Anabilim Dal, Ziraat fakültesi, Kahramanmaraş Sütçü Imam Üniversitesi, \\ Kahramanmaraş, Türkiye \\ ${ }^{2}$ Tarımsal Biyoteknoloji Anabilim Dall, Ziraat Fakültesi, Kahramanmaraş Sütçü İmam Üniversitesi,
} Kahramanmaraş, Türkiye

\begin{abstract}
Özet
Tekstil sanayinin önemli hammaddesi olan pamuk özellikle doğal lifleri için yetiştirilmektedir. Bu nedenle lif oluşumu ve olgunlaşma aşamaları birçok araştırmanın konusu olmuştur. Pamukta lif uzamasıyla ilgili genlerin, pamuk ıslah çalışmalarında sıkça kullanılan germplazm içerisinde dağılımlarını ve polimorfizm durumlarını incelemek amacıyla yapılan bu çalışmadafarklı türlere ait toplam 247 adet genotip arasından liflerinin uzun, orta, kısa ve lifsizlik özellikleri dikkate alınarak seçilen 35 adet pamuk genotipi materyal olarak kullanılmıştır. Seçilen pamuk genotipleri, Gossypium barbadense L.(1-9), Gossypium hirsutumL.(10-25) ve diğer diploid ve tetraploidler; Gossypium herbaceum L. (26), G.laxum Phillipe (27), G.yucatanense (28), G.marie galante (29), G.mustelinum Miers ex Watt (30), G.darwinii Watt (31), G.nelsonii Fryx. (32), G.Stocksii Mast. ex Hook. (33), G.areysianum Defl. Hutch. (34), G.bickii Prokh (35) türlerinden seçilmiştir. Ayrıca, lifsiz (23), PI 528429 (24) ve PI 528426 (25) genotipleri lifsiz özellikte olup, seçilen yabani genotipler A, D, AD, C, E ve G genomlarını kapsamaktadır. Lif uzamasında etkili olduğu düşünülen genler geniş bir literatür taraması yapılarak belirlenmiş ve bunların homolojilerine bakılarak 4 adet primer tasarlanmıştır. Bu primerlerin tamamı kullanılarak pamuk genotiplerinde amplifikasyon yapılmış ve bu sonuçlar doğrultusunda genotipler arasında önemli farklılık gösteren CesA genine odaklanılmıştır. Fenotipleme neticesinde, G.barbadense genotipleri uzun ve kaliteli lifler, G.hirsutum genotipleri ise orta kalite ve orta uzunlukta lif üretmiştir. Çalışmada, seçilen genotiplerde lif uzunluğunun ortalama değeri 25,25 mm olup, 0- $36 \mathrm{~mm}$ arasında değişmiştir. PI 528896 (1) genotipi $36 \mathrm{~mm}$ ile en uzun lif özelliğine sahiptir. Genotiplerin birçoğunun lif uzunluğu 22 - 33 mm arasında değişmiştir. Bununla birlikte, yaklaşık olarak 500-510 bp uzunluğundaki allellerin SNP taşıdığı ve 2 allelde bulunan bu SNP’lerin amino asit değişimine neden olduğu belirlenmiştir. Bu değişimlerin lif kalitesiyle ilişkili olabileceği ve daha detaylı çalışmaların yapılması gerektiği sonucuna varılmıştır.
\end{abstract}

Anahtar Kelimeler: Lif Kalitesi, Lif Uzunluğu, Gen, Polimorfizm, GhCesA, Pamuk

\section{Polimorfizm of the Genes Related to Cotton Fiber Elongation}

\begin{abstract}
Cotton isespecially grown for natural fibers which is an important raw material for textile industry. For this reason, fiber initiation and maturation steps are the subject of many researches. The goal of this study is to determine polymorphism of the genes related to cotton fiber elongation and distribution throughout the germplasm. Plant materials used in the experiment were total of 35 genotypes that were selected out of 247 according to length character of the fiber. The species in which cotton genotypes were belong are Gossypium barbadense L. (1-9), Gossypium hirsutum L. (10-25) and other diploids and tetraploids; Gossypium herbaceum L. (26), G.laxum Phillipe (27), G.yucatanense (28), G.marie galante(29), G.mustelinum Miers ex Watt(30), G.Darwinii Watt(31), G.nelsonii Fryx. (32), G.Stocksii Mast. ex Hook. (33), G.areysianum Defl. Hutch. (34) and G.bickii Prokh (35). Selected genotypes also include fiberless traits in Lifsiz (23), PI 528429 (24) and PI 528426 (25) genotypes. Genes related to fiber elongation were determined after a wide literature search and 4 primers were designed according to their homologies. After screening 35 genotypes with the primers, CesA gene had more polymorphism. Phenotyping resulted long and fine fibers for G.barbadense while medium length and quality fibers for G.hirsutum. Averaged fiber length was $25.25 \mathrm{~mm}$ and it ranged from 0 to $36 \mathrm{~mm}$. PI 528896 (1) had the longest fiber length that ranged from 22-23 mm for most of the genotypes. With this, alleles
\end{abstract}

*e-mail: gulayzulkadir@ksu.edu.tr 
(500-510 bp) with SNPs were determined and two of them caused amino acid change in the sequence. This change may be related to fiber length but detailed work is needed.

Keywords: Fiber Quality, Fiber Elongation, Gene, Polymorphism, GhCesA, Cotton

\section{Giriş}

Pamuk lifi tekstil sanayisinde hammadde olarak kullanıldığı için büyük önem taşımakta ve pamuk mahsulünün ekonomik değerinin yaklaşık \% 90’ını oluşturmaktadır [1]. Pamuk lifi, tohumun epidermal tabakasındaki hücrelerde, her biri tek bir hücrenin farklılaşarak uzamasıyla oluşan trikom (trichomes) olarak adlandırılan yapılardır[2]. Gelişmeleri hücre bölünmesi veya çok hücreli (multicellular) gelişme şeklinde olmaz ve yüksek bitkiler içerisinde en uzun tek hücredir. İlave olarak, olgun liflerin neredeyse tamamı (yaklaşı \%90) tek hücre duvarı biyopolimeri olan selüloz'dan oluşmuştur [3].

Lif oluşumu çiçeklenmeyle (anthesis) başlar ve bu evrede tohum yüzeyinde küresel şişkinlikler görülebilir. Bu küresel şişkinlikler, hücre uzamasıyla devam eder. Bu evreden 2-3 gün sonra, lif uçları sivrilmeye ve koni şeklini almaya başlar. Lif hücreleri, anthesis'den sonra 3 hafta içerisinde yaklaşık $30 \mathrm{~mm}$ ' ye kadar uzayabilirler. Sekonder hücre duvarı (anthesisden 3-6 haftalık dönem) kalın bir duvarın oluşmasıyla önceki safhadan ayrilır [4].

Anthesis süresince gelişen ovüllerde, lif oluşumu "quasi-synchronous" olarak adlandırılan; aynı mesajın birden fazla iletici molekül aracılı̆̆ıla aynı hızda yayılması veya iletilmesini kapsayan bir süreç olarak tanımlanmaktadır. Pamukta lif gelişimi 4 safhaya ayırılmıştır: 1. Oluşum (initiation, differentiation) 2. Uzama (expantion, elongation) 3. Sekonder hücre duvarı oluşumu (Secondary wall thickening) ve 4. Olgunlaşma (maturation) [5, 6]. Lifin gelişme süresi ve oranı direk olarak lif kalitesini etkilemektedir. Lif kalitesi sanayi açısından çok önemlidir ve çoğunlukla genetik faktörler tarafından kontrol edilmektedir [7]. Tozlaşmanın hemen ardından gerçekleştiği için lif oluşumunun moleküler aşamaları tam olarak anlaşılamamıştır. Bu nedenle lif oluşturan hücrelerin (protodermal cells) lif oluşumuna ne zaman ve nasıl katıldıklarını bilmek çok zordur. Bu konudaki moleküler çalı̧̧malar da oldukça kısttlidır. Lif oluşumuna; genler kontrolünde hücre döngüsü, transdüksiyon, hormonlar, sitoskeleton yapı, karbonhidrat içeriği ve hücre duvarının protein yapısı dolaylı olarak etkide bulunmaktadır. Ancak bunların etkilerinin ne ölçüde olduğu tam olarak bilinmemektedir [8-11].

Lif oluşumuyla ilgili klonlanan ve üzerinde çalışılan genlerden bazıları; glutamin sentetaz (GhGS) [1214], brassinosteroid sentetaz GhDWF1 [15], Myb109 ve MYB2 lif oluşumu sırasında ifade edilen (ekspres) transkripsiyon faktörleri[16], kinesin proteini GhKCH1 [17] ve GhKCH2 [18], Sucrose Synthase (SuSy) [19], transporter proteini GhWBC1 [20] ve GhRac1 geni lif uzaması aşamasında yüksek oranda ekspres olmaktadır [21].

$\mathrm{Bu}$ genlerden çalışmamızda seçilen CesA geni, selüloz sentezinin katalitik alt ünitelerini kodlayan ve Arabidopsis'de karakterize edilen bir gendir. Genomda bilinen ve bilinmeyen fonksiyonları olmak üzere iki gruba ayrılmaktadır [22, 23]. CESA1, CESA3 ve CESA6 genlerini içeren birinci grup genellikle genişleyen dokularda ifade edilmekte [24-26] ve cesA1, cesA3 ve cesA6 mutantları cüce kalmakta veya fideler ölmektedir. CESA4, CESA7, CESA8 ve cesA4, cesA7 ve cesA8 mutantlarını içeren diğer grupta ise ksilemlerdeki karakteristik ikincil kalınlaşmada azalma görülmektedir [27-29]. Geriye kalan CESA2, CESA5, CESA9 ve CESA10 genlerinin fonksiyonları tam olarak anlaşılmamış olmasına rağmen, son zamanlardaki çalışmalar, 
bazılarının işlevsel olarak gereksiz olduğunu ve/veya farklı fizyolojik durumlar altında diğer CESA genlerinin fonksiyonlarına yardımcı olabileceğine işaret etmektedir [30, 31].

Lif kalitesi üzerine etki eden genlerin yerlerinin, fonksiyonlarının ve bunların ne şekilde aktive olduklarının bilinmesi bize daha verimli ürünler elde etmemiz, bunları daha az zahmetle ve daha kolay elde edebilmemiz açısından büyük imkânlar sağlamaktadır. Bu amaçla da çalışmalarda genellikle DNA markörleri kullanılmaktadır. PCR'ye dayalı DNA markörleri; AFLP (Amplified Fragment Lenght Polymorphism), RAPD (Randomly Amplified Polymorphic DNA), SSR (Simple Sequence Repeat), STS (Sequenced-Tagged Sites) ve EST-SSR (Exppressed Sequence Tags-SSR) pamukta genetik haritaların yapılmasında geniş bir şekilde kullanılmaktadır [32-42].

DNA markörleri ile belirlenebilen QTL’lerin ilgilenilen agronomik ve lif özelliklerine katkı sağlaması mümkündür. Pamukta özellikle lif kalite karakterlerini kontrol eden genlerin belirlenmesi ve islahta kullanımına yönelik çalışmalar artmaktadır [43-56]. Bu nedenle, gerek rastgele primerler kullanılarak ve gerekse de dizilimleri bilinen sekanslardan yararlanarak lif kalitesini kontrol eden gen veya QTL'lerin belirlenmesi ve bu karakterlere yakın markörlerin haritalanması öncelikli hedefler arasındadır. Ayrıca, bir gen için farklı alellerin belirlenmesi durumunda, gen piramitleme çalışmaları da yapılabilecektir.

Pamuk lif oluşumu ve gelişmesiyle ilişkili bu genlerin açılım gösteren düzenli populasyonlarda araştırılması ve ıslah amacıyla kullanılmaları önemlidir (RFLP-PCR metodu, özellikle tek genle kontrol edilen karakterleri populasyonda taramak ve SNP bulmak amacıyla kullanılan bir yöntemidir). Bu çalışmada, lif kalitesiyle ilgili bulunan genler farklı lif özelliklerinesahip pamuk germplasmı içerisinde taranarak, lif kalitesini nasıl etkiledikleri (polimorfizm durumları) ve MAS amacıyla kullanılma olasılıkları araştırılacaktır.

\section{Materyal ve Metot}

\subsection{Materyal}

Gossypium hirsutum L., Gossypium barbadense L., Gossypium herbaceum L.ve Gossypium arboreum L. türlerini kapsayacak şekilde 247 adet genotip arasından liflerinin uzun, orta, kısa ve lifsizlik özellikleri dikkate alınarak seçilen 35 adet pamuk genotipi materyal olarak kullanılmıştır.

\subsection{Metot}

\subsubsection{Tarımsal İșsemler}

\subsubsection{Toprağın ekim için hazırlanması}

Tarla, yabancı ot durumuna göre iki kez kültivatör ile yüzlek olarak işlenmiş, dekara saf olarak $8 \mathrm{~kg}$ azot $(\mathrm{N})$ ile $8 \mathrm{~kg}$ fosfor $\left(\mathrm{P}_{2} \mathrm{O}_{5}\right)$ baz alınarak gübreleme (20-20-0) yapılmış ve iki kez tapan çekilmiştir.

\subsubsection{Ekim}

Araştırma, Kahramanmaraş Tarımsal Araştırma Enstitüsü Müdürlüğü'nde (Şekil 3.1), 2010 yılında ve ÜSKIM Bitki Moleküler Genetik Laboratuvarında 2011 yılında yürütülmüştür. Denemede yer alan 247 adet genotip, 11 Mayıs 2010 tarihinde 5 m'lik sıralara 2 tekerrürlü olarak ekilmiş ve ayrıca el ile parsel etrafına kenar tesiri olarak Famosa çeşidi ekilmiştir.

\subsubsection{Bakım}

Fidelerin kök gelişimi ve yabancı otlardan temizlenmesi amacıyla 4 kez el çapası, 2 kez elle boğaz doldurma ve $2 \mathrm{kez}$ traktör çapası yapılmıştır. İki defa olmak üzere üst gübre uygulaması $(8.25 \mathrm{~kg} / \mathrm{da}$ saf azot 
olacak şekilde \%33'lük Amonyum Nitrat) yapılmıştır. İlkinde $5.2 \mathrm{~kg} / \mathrm{da}$ ilk sulamadan önce gübre mibzeri ile sıra aralarına uygulanmış ve azotun geri kalan kısmı ise ikinci sulamadan önce gübre mibzeri ile sıra aralarına uygulanmıştır. Bitkinin ihtiyacı ve toprağın durumu dikkate alınarak ihtiyaca göre sulama yapılmış ve lifler olgunlaşma sürecini tamamladıktan sonra sulamalara son verilmiştir

\subsubsection{Hasat ișlemi ve lif uzunluğunun belirlenmesi}

Birinci ve ikinci meyve dalları üzerinde, birinci pozisyondan alınan kozalar lif analizi için 10 Eylül 2010 tarihinde toplanmıştır. Elde edilen lifler, rollergin çırçırında elyaf ve tohum unsurlarına ayrılmıştır. Elyaf özellikleri, HVI 900 Spectrum ile analiz edilmiş ve lif uzunluk (length) değerleri belirlenmiştir. Analiz sonuçlarına göre moleküler aşamada kullanılacak 35 adet genotip Gossypium hirsutum ve Gossypium barbadanse türleri içerisinden lif uzunluk değerleri, üretim durumları dikkate alınarak seçilmiştir. Seçim işlemi, tarımsal açıdan uygun olanlardan panel oluşturularak, bulunan uygun alleller daha sonra melezlerde kullanılmıştır.

\subsection{Moleküler Çalışmalar}

\subsubsection{Biyoinformatik analizler}

\subsubsection{Lif oluşumu ve uzamasıyla ilişskili genlerin belirlenmesi}

Lif uzunluğu üzerine etkisinin olduğu düşünülen genler EST kütüphaneleri (Gen Bank) ve yayınlanmış makaleler taranarak belirlenmiştir. Belirlenen toplam 4 adet gen, Clone Maneger 5 programı kullanılarak analiz edilmiştir. Bu analiz sonucunda eldeki genlerin genelinde bir homoloji tespit edilememiştir. Ancak aralarında homoloji bulunduğu tespit edilen genler kendi aralarında gruplandırılmıştır (EK-1). Bu nedenle de, geniş bir makale taraması yapıldıktan sonra lif uzaması özelliğine katkısı en fazla olduğu düşünülen genler belirlenmiştir.

\subsubsection{Sekans analizleri}

Bulunan genler DNAstar software programında analiz edilmiş, NCBI adresindeki Blast software programında genlerin nükleotit dizileri taranmışıtır. Elde edilen sekanslar ClustalX software (version 1.81) programında karşılaştırılmıştır [57]. Filogenetik analiz ise PHYLIP in ClustalX (version 1.81) programı ile yapılmıştır [57].

\subsubsection{Primer tasarlanması}

Belirlenen genlerden mevcut germplazmin taranması ve genlerin yerlerinin haritalanması amaciyla primerler tasarlanmıştır (Tablo 4.3).

Primerlerin tasarlanması için ilgili genlerin yerleri Clone Manager programı ile analiz edilerek, ilgili bölgeyi tanıyabilecek primerler tasarlanmıştır.

Clone Manager'daki gen analizi neticesinde tasarlanmış olan primerlerin hesaplamaları internet tabanlı olan DNA Calculation (www.sigma-genosys.com/order_DNACalc.asp ) programında yapılmıştır.

\subsection{Genotipleme Çalıșmaları}

\subsubsection{DNA izolasyonu}

DNA izalasyonu; MACHEREY-NAGEL NucleoMag 96 Plant kiti kullanılarak ve sonrasında KingFisher DNA izalasyon cihazı kullanarak yapılmıştır. Öncelikle yapraklar sıvı azot ile öğütülmüş ve 1,5 ml ependorf tüplere öğütülmüş yaprak örneklerinden 10-20 mg eklenerek üzerine $500 \mu 1 \mathrm{MC} 1$ buffer ve $10 \mu 1 \mathrm{RNaz}$ ilave edilmiştir. Karışım, $57{ }^{\circ} \mathrm{C}$ de 30 dakika bekletildikten sonra 5600 devirde 20 dakika santrifüj edilerek 
yaprak parçalarının çökmesi sağlanmış, üstteki sıvı kısımdan 95 $\mu 1$ 'plate'in A kuyucuğuna eklenmişstir. Sonraki aşamalar:

96'lık DNA izolasyon 'plate'inin; A kuyucuğuna $95 \mu 1$ cleared lysate $+95 \mu 1 \mathrm{MC} 2$ buffer $+10 \mu 1 \mathrm{C}$ beads, B kuyucuğuna $180 \mu \mathrm{l}$ wash buffer MC3, C kuyucuğuna $180 \mu \mathrm{l}$ wash buffer MC4, D kuyucuğuna $180 \mu 1$ 80\% ethanol, E kuyucuğuna $180 \mu \mathrm{l}$ wash buffer MC5, F kuyucuğuna $50 \mu 1$ Elution Buffer MC6 eklenmiş ve KingFisher DNA izolasyon cihazına bırakılıp cihaz çalıştırılmıştır.

KingFisher DNA izolasyon cihazından 'plate' çıkarılarak çözünmüş DNA'lar 0,2 ml PZR tüplere aktarılmıştır ve böylelikle izolasyon işlemi tamamlanmıştır.

\subsection{2. İzole edilen genomik DNA'ların agaroz jel elektroforez yöntemi ile gösterimi}

1. \%1'lik agaroz jel hazırlamak için 2,5 gram agaroz tartılarak $250 \mathrm{ml} 1 \mathrm{X}$ TAE içerisine konulmuş, mikrodalga firında taşmamasına özen gösterilerek agaroz tamamen eriyene kadar kaynatılmıştır. Daha sonra oda ısısında veya musluk suyu altında elle dokunulabilir sıcaklığa erişene kadar soğutulup, kabarcıkların oluşmamasına dikkat edilerek tank aparatına dökülmüştür.

2. Jel tarakları elektroforez tankında uygun yerlere yerleştirilerek, 3-5 mm kalınlığında bir jel dökülüp, hava kabarcı̆̆ı oluşmuş ise pipet ucu veya kağıt peçete yardımıyla ortamdan uzaklaştırılmıştır.

3. Jel tamamen donduktan sonra taraklar kuyucukların bozulmamasına özen gösterilerek çıkartılıp, içerisinde 1X TAE bulunan tanka yerleştirilmiştir. Tampon çözeltisinin agaroz jelin üzerini 1mm’yi aşmamasına dikkat edilmiştir.

4. Jel üzerindeki ilk kuyucuğa DNA standartı yüklenmiştir.

5. İzole edilen genomik DNA örneklerinden $8 \mu \mathrm{l}$ alınıp, $2 \mu \mathrm{l}$ jel yükleme tamponu (6X) eklenmiştir. Pipet yardımıyla iyice karıştırılıp, jel üzerindeki kuyucuklara dikkatlice yüklenmiştir.

6. Elektrotların doğru olarak yerleştirildiğinden emin olduktan sonra voltaj 1-5 V/cm olacak şekilde hesaplanmıştır (cm, pozitif ve negatif elektrot arasındaki uzaklıktır). Mini jellerde ise 10-100 ng DNA 30-60 dakika içerisinde 5-20 V/cm olacak şekilde yürütülmüştür.

7. Yükleme tamponunun görülebilir boyaları jelin 2/3'üne ulaştığında yürütme durdurulmuştur.

8. Jel transiluminatörde UV ışı̆̆ı altında gözlemlenmiştir.

\subsubsection{DNA miktar tayini}

Her örnekteki DNA miktarı $260 \mathrm{~nm}$ dalga boyunda spektrofotometrede ölçülen absorbans değerleri $\left(\mathrm{A}_{260}\right)$ kaydedilerek; DNA $(\mu \mathrm{g} / \mathrm{ml})=260 \mathrm{~nm}$ 'de ölçülen absorbans değeri x sulandırma oranı x çift iplikçikli DNA için standart katsayı $(50 \mu \mathrm{g} / \mathrm{ml})$ formülü kullanılarak hesaplanmıştır. DNA kalitesi ve saflığı hakkında bilgi veren 230 ve $280 \mathrm{~nm}$ dalga boylarındaki absorbans değerleri $\left(\mathrm{A}_{230}\right.$ ve $\left.\mathrm{A}_{280}\right)$ de ayrıca incelenmiştir.

\subsubsection{Genotipik analiz}

Elde edilen primerler kullanılarak pamuk genotipleri PCR-RFLP yöntemi ile taranmıştır.

\subsubsection{Polimeraz zincir reaksiyonu (PCR)}

Çalışmada belirlenen 4 adet primer yapılan analizler sonucu belirlenmiştir. Bu primerlerin isimleri, nükleotit dizilimleri, yapışma sıcaklık değerleri (Tablo 4.3) verilmiştir.

PCR; $0.2 \mathrm{ml}$ hacminde 96'llk PCR tüplerine;

$1 \mu \mathrm{dNTP}$ karışımı $(10 \mathrm{mM}$ karışım $(\mathrm{A}+\mathrm{T}+\mathrm{G}+\mathrm{C})), 2 \mu \mathrm{l}$ 10x buffer,2,5 $\mu 1 \mathrm{MgCl}_{2}$,primer çifti $(1 \mu \mathrm{F}$ ve 1

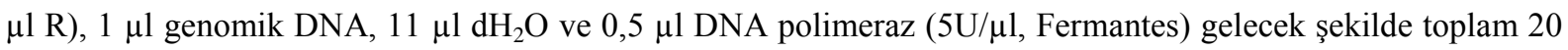
$\mu 1$ solüsyon hazırlanmıştır. 
PCR reaksiyonları "Eppendorf Mastercycler Gradient” marka PCR cihazında; $94{ }^{\circ} \mathrm{C}$ 'de 3 dakika çalıştıktan sonra $94{ }^{\circ} \mathrm{C}$ (DNA iplikçiklerinin ayrışması) 30 saniye, $65^{\circ} \mathrm{C}$ (primerlerin yapışması) 30 saniye ve 72 ${ }^{\circ} \mathrm{C}$ (DNA eşleşmesi)'de 2 dakika çalışarak, $94^{\circ} \mathrm{C}$ ile $72^{\circ} \mathrm{C}$ arasında 35 döngü yapması sağlanmış ve son aşamada $72{ }^{\circ} \mathrm{C}$ 'de 5 dakika çalıştırılarak tamamlanmıştır. Bitirilen PCR ürünleri kullanıma kadar $-20{ }^{\circ} \mathrm{C}$ 'de bekletilmiştir.

\subsubsection{PCR sonrası agaroz jel analizi}

Elektroforez;

\% 3'lük agaroz [7.5 gr Agaroz + $250 \mathrm{ml}$ 0.5×TBE (Tris-Brote-EDTA Tamponu)] jel hazırlanmıştır.

PCR ürünleri yükleme solüsyonu ile yükleme kuyularında $10 \mu 1$ PCR ürünü ve $3 \mu 1$ yükleme solüsyonu olacak şekilde karıştırılarak elektroforez tankının içine yerleştirilen jel üzerine yüklenmiş ve $100 \mathrm{~W}, 50$ A'de 5 saat çalıştırılmıştır.

Elektroforez işlemi tamamlandıktan sonra jel etidium bromide solusyonuna (100 ml 1xTBE için $30 \mu \mathrm{l}$ etidium bromür eklenecek) 20 dakika bırakılarak daha sonra saf su içerisinde 10 dakika bekletilmiştir.

Son olarak UV altında görüntülenerek resmi alınmıştır.

Görüntüleme neticesinde bantlardaki farklılık daha iyi gözlenmiştir. Bu bantların kurtarılması amacıyla \%4'lük agaroz jelle 50 W/25 A 14 saat elektroforez yapılmıştır. Burada görüntülenen herbir DNA bandı temiz bir bistüri yardımı ile dikkatli bir şekilde kesilerek alınmış ve darası alınan temiz bir mikrosantrifüj tüpüne konarak miktarı tespit edilmiştir.

DNA, GF-1 DNA izolasyon kitiyle (FAVORGEN) üretici firmanın talimatlarına göre agaroz jelden arındırılmıştır.

\subsubsection{Nükleik asit ekstraksiyonu}

Kesilip tartımı yapılan jellerin üzerine kendi ağırlığı kadar Buffer GB (0,1g jele $100 \mu$ l GB Buffer) eklenmiş ve $50{ }^{\circ} \mathrm{C}$ 'de jel tamamıyla eriyinceye kadar inkübe edilmiştir. Eriyen jel pipet yardımıyla kolonlara aktarılmış ve $10,000 \times \mathrm{g}$ devirde $1 \mathrm{dk}$ santrifüj edilerek alttaki sıvı dökülmüştür. Ardından kolona $750 \mu 1$ Wash Buffer eklenerek 10,000×g devirde $1 \mathrm{dk}$ santrifüj edilip alta sızan sıvı boşaltılmıştır. Kolonda sıvı kalmaması için tekrar 10,000×g devirde $1 \mathrm{dk}$ santrifüj edilip sızan sıvı boşaltılmıştır. Kolonlar yeni mikrosantrifüj tüplerine alınarak kolon üzerine 30-50 $\mu$ l Elution Buffer eklenmiş ve $2 \mathrm{dk}$ beklemeye bırakılmıştır. Ardından tekrar $10,000 \times \mathrm{g}$ devirde $1 \mathrm{dk}$ santrifüj edilmiş ve alta geçen sıvı (DNA) $4{ }^{\circ} \mathrm{C}$ veya $-20{ }^{\circ} \mathrm{C}$ de saklamaya bırakılmıştır.

Elde edilen DNA'lar yeni bir PCR protokolü uygulanarak çoğaltılmıştır.

PCR; $0.2 \mathrm{ml}$ hacminde 96'lık PCR tüplerine; $1 \mu \mathrm{ldNTP}$ karışımı (10mM karışım $(\mathrm{A}+\mathrm{T}+\mathrm{G}+\mathrm{C})), 2 \mu \mathrm{l}$ 10x buffer,2 $\mu 1 \mathrm{MgCI}_{2}$,primer çifti $\left(1 \mu \mathrm{l} \mathrm{F}\right.$ ve $1 \mu \mathrm{l}$ ), $2 \mu$ l genomik DNA, 32,5 $\mu 1 \mathrm{dH}_{2} \mathrm{O}$ ve 0,5 $\mu 1$ DNA polimeraz (5U/ $\mu 1$, Fermantes) gelecek şekilde toplam $42 \mu$ l solüsyon hazırlanmıştır. PCR reaksiyonları "Eppendorf Mastercycler Gradient” marka PCR cihazında; $94{ }^{\circ} \mathrm{C}$ 'de 3 dakika çalıştıktan sonra $94{ }^{\circ} \mathrm{C}$ (DNA iplikçiklerinin ayrışması) 30 saniye, $65^{\circ} \mathrm{C}$ (primerlerin yapışması) 30 saniye ve $72{ }^{\circ} \mathrm{C}$ (DNA eşleşmesi)' de 2 dakika çalışarak, $94^{\circ} \mathrm{C}$ ile $72^{\circ} \mathrm{C}$ arasında 35 döngü yapması sağlanmış ve son aşamada $72{ }^{\circ} \mathrm{C}$ de 5 dakika çalıştırılarak tamamlanmıştır. Bitirilen PCR ürünleri kullanıma kadar -20 $\mathrm{C}^{\circ}$ de bekletilmiştir. PCR hazırlandıktan sonra \%2'lik agaroz jelde koşturma işlemi yapılmıştır. Elektroforez sonucunda bantların teke düşürülmesi gerçekleştikten sonra sekans işlemine geçilmiştir.

\subsubsection{Dizi sekans}


PCR-RFLP sonucuna göre (bant uzunluklarına ve lif özellikleri dikkate alınarak) yapılan gruplandırmada seçilen örnekler sekanslanmıştır. Oluşturulan sekans bilgileri blast programı ile mevcut dizilerle karşılaştırılmıştır.

\subsubsection{Verilerin istatiksel değerlendirilmesi}

Ortalamalar arasındaki farklılıklar ve önem dereceleri SAS [58] istatistik programı kullanılarak belirlenmiştir.

\section{Bulgular}

\subsection{Lif Analizleri ve Fenotipik Seleksiyon}

Denemede ekimi yapılan G. hirsutum ve G. barbadase çeşitleri ağırlıklı olmak üzere 247 adet genotip hasat edildikten sonra lifler çırçırlanmış sonra HVI 900 Spectrum ile lif uzunluğu analiz edilmiştir. Analiz sonuçlarına göre moleküler aşamada kullanılacak 35 adet genotip, Gossypium hirsutum ve Gossypium barbadanse türleri içerisinden lif uzunluk değerleri, üretim durumları, agronomik ve genom özellikleri dikkate alınarak seçilmiştir (Tablo 4.1).

Ekimi yapılan 247 adet genotipin uzunluk verileri dikkate alınarak (uzun, orta, kısa ve lifsiz olma durumlarına göre) seçim yapabilmek amacıyla karşılaştırma yapılmıştır. $\mathrm{Bu}$ karşılaştırma neticesinde Tablo 4.1'deverilen 35 genotip seçilmiş ve moleküler çalışmalarda kullanılmıştır.

Genotipler PI528806 (1) ve Giza-45 (2)'in lifleri ekstra uzun bulunurken, GB620 Moc/22 (3), Aşkabat91 (4), Aşkabat-100 (5), Bahar-14 (6), İs-4 (7), Bahar-82 (8), Aşkabat-71 (9) ve Carmen (10) uzun lifli bulunmuştur. Bununla birlikte, genotipler Maraş-92 (11), Nazilli-845 (12), Suregrow-125 (13) ve Stonville-468 (14) ortadan biraz uzun, Ekstrem Okra (15), YB-225 (16), TX 0060-2 (17), YB-141 (18), PI 528420 (19), YB216 (20), YB-222/2 (21) ve PI 528450 (22) ise kısa lifli olarak ölçülmüştür (Tablo 4.1).

Lif uzunluğunun ortalama değeri 25,25 mm olup, 0- $36 \mathrm{~mm}$ arasında değişmiştir. Genotiplerin büyük çoğunluğunun (PI 528450, G.B.620 Moc/22, Aşkabat-91, Aşkabat 100, Bahar-14, İs 4, Bahar 82, Aşkabat-71, Carmen, Maraş 92, Nazilli 845, Suregrow 125, Stonville 468, Ekstrem Okra (Brown), Kahverengi, TX 0060-2, Yeşil Lif, PI 528420, Yeşil Lif, Havsız Lifli) lif uzunluğu 22-33 mm arasında değişmiştir. Genotipler; YB-109 (23), PI 528429 (24) ve PI 528426 (25) lifsiz özellik göstermektedirler. Bununla birlikte PI 528896 (1) genotipinin $36 \mathrm{~mm}$ ile en uzun lif özelliğine sahip olduğu gözlenmiştir.

Lif özellikleri için yapılan varyans analizinde eşitler arasında çok önemli farklılıklar $(\mathrm{p}<0.01)$ olduğu belirlenmiştir. Varyasyon katsayısı değeri \%0,003 olarak bulunmuştur (Tablo 4.1).

Tablo 4.1. Lif özelliklerine göre moleküler çalışmalarda kullanmak amaciyla seçilen genotipler

\begin{tabular}{|c|c|c|c|c|}
\hline No & Tür & Genotip & $\begin{array}{c}\text { L.U } \\
(\mathrm{mm})\end{array}$ \\
\hline 1 & G.barbadense & PI 528896 & Lifleri ekstra uzun \\
2 & G.barbadense & Giza-45 & 34,4 & Lifleri ekstra uzun \\
3 & G.barbadense & G.B.620 Moc/22 & 33,9 & Lifleri uzun \\
4 & G.barbadense & Aşkabat-91 & 33,8 & Lifleri uzun \\
5 & G.barbadense & Aşkabat 100 & 33,1 & Lifleri uzun \\
6 & G.barbadense & Bahar-14 & 33,1 & Lifleri uzun \\
7 & Gossypium sp. & İs 4 & 33 & Lifleri uzun \\
\hline
\end{tabular}


Zülkadir G., Bölek Y.

\begin{tabular}{|c|c|c|c|c|}
\hline 9 & G.barbadense & Aşkabat-71 & 32,6 & Lifleri uzun \\
\hline 10 & G.hirsutum & Carmen & 29,4 & Lifleri uzun \\
\hline 11 & G.hirsutum & Maraş 92 & 28 & Lifler ortadan biraz daha uzun \\
\hline 12 & G.hirsutum & Nazilli 845 & 28,2 & Lifler ortadan biraz daha uzun \\
\hline 13 & G.hirsutum & Suregrow 125 & 28 & Lifler ortadan biraz daha uzun \\
\hline 14 & G.hirsutum & Stonville 468 & 27,6 & Lifler ortadan biraz daha uzun \\
\hline 15 & G.hirsutum & Ekstrem Okra (Brown) & 23 & Lifleri kısa \\
\hline 16 & G.hirsutum & Kahverengi & 22,8 & Lifleri kısa \\
\hline 17 & G.hirsutum & TX 0060-2 & 22,7 & Lifleri kısa \\
\hline 18 & G.hirsutum & Yeşil Lif & 22,6 & Lifleri kısa \\
\hline 19 & G.hirsutum & PI 528420 & 22,6 & Lifleri kısa \\
\hline 20 & G.hirsutum & Yeşil Lif & 22,1 & Lifleri kısa \\
\hline 21 & G.hirsutum & Havsız Lifli & 27,7 & Lifler ortadan biraz daha uzun ve havsız \\
\hline 22 & G.hirsutum & PI 528450 (Az Havlı) & 23,7 & Lifler orta uzunlukta ve havsız \\
\hline 23 & G.hirsutum & Lifsiz & 0 & Lifsiz \\
\hline 24 & G.hirsutum & PI 528429 (Lifsiz) & 0 & Lifsiz \\
\hline 25 & G.hirsutum & PI 528426 (Lifsiz) & 0 & Lifsiz \\
\hline 26 & G. herbaceum L. & A Genomu & - & yabani tip (wild type 1 (A)) \\
\hline $27 *$ & G. laxum Phillipe & D Genomu & - & yabani tip (D9-3 (P)) \\
\hline $28^{*}$ & G. yucatanense & AD Genomu & - & yabani tip ((AD)1-1469) \\
\hline $29 *$ & G. marie galante & AD Genomu & - & yabani tip ((AD)1-1607) \\
\hline $30 *$ & G. mustelinum Miers ex Watt & AD Genomu & - & yabani tip ((AD)4-9) \\
\hline $31 *$ & G. darwinii Watt & AD Genomu & - & yabani tip ((AD)5-14, (AD)5-3) \\
\hline $32 *$ & G. nelsonii Fryx. & C Genomu & - & yabani tip (C9-1 (P)) \\
\hline $33^{*}$ & G. stocksii Mast. ex Hook. & E Genomu & - & yabani tip (E1-2, E1-1) \\
\hline $34^{*}$ & G. areysianum ( Defl ) Hutch. & E Genomu & - & yabani tip (E3-1) \\
\hline $35^{*}$ & G. bickii Prokh. & G Genomu & - & yabani tip (G1-4, G1-1 (P)) \\
\hline \multicolumn{5}{|c|}{ Ortalama } \\
\hline \multicolumn{5}{|c|}{ Minim } \\
\hline \multicolumn{5}{|c|}{ Maksimum } \\
\hline \multicolumn{5}{|c|}{ Standart Sapma } \\
\hline \multicolumn{5}{|c|}{ Varyasyon Katsayısı } \\
\hline
\end{tabular}

Lif uzunluğu ve varyans analiz sonuçları incelendiğinde genotiplerin genelinde farklılıklar gözlenmesinin yanı sıra G.barbadense ve G.hirsutum genotiplerinin kendi içlerinde benzer, birbirleri arasında büyük farklılıkların olduğu bulunmuştur. Ancak G. hirsutum (23), PI 528429 (24) ve PI 528426 (25) genotipleri lifsiz olduğu için diğer genotiplerden çok daha fazla farklılık göstermiştir.

\subsection{Genlerin Belirlenmesi ve Bu Genlere Ait Primerlerin Tasarlanması}

Lif uzamasıyla ilişkili genler EST kütüphaneleri ve yayınlanmış makalelerde taranarak belirlenmiştir (Tablo 4.2). Belirlenmiş olan bu genler Clone Maneger 5 programı kullanılarak aralarında homoloji olma durumlarına göre incelenmiş, genlerin genelinde bir homoloji tespit edilememesi üzerine lif uzaması özelliğine etkisinin en iyi olduğu düşünülen genler etki mekanizmalarına göre gruplandırılmış ve her bir grubun kendi 
içindeki homolojilerine bakılarak genler belirlenmiştir. Bulunan genlerin nükleotid dizileri analiz edilerek bu genlere uygun primerler oluşturulmuştur (Tablo 4.2).

Tablo 4.2. Moleküler çalışmalarda kullanmak amacıyla lif uzunluğunu etkileyen genler için tasarlanan primerler

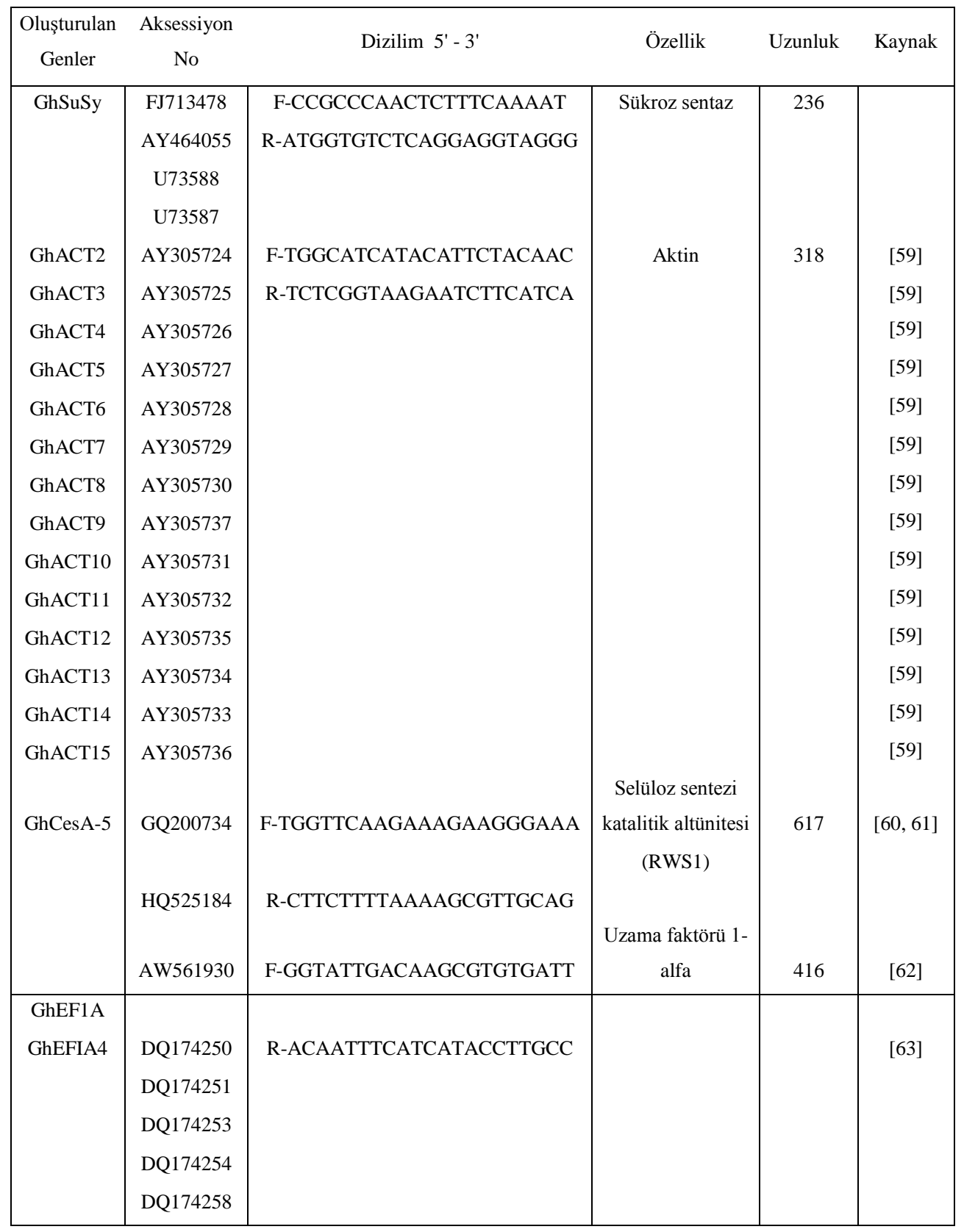

\subsection{Genotipleme Çalış̧maları}

\subsubsection{DNA izolasyonu ve genomik DNA'ların agaroz jel yöntemiyle gösterimi}

Lif özelliklerine göre belirlenen genotiplerde DNA izolasyonu 2.4.1'de verilen yönteme göre yapılmıştır. İzole edilen genomik DNA'lar \%1'lik agaroz jelde koşturularak görüntülenmiştir (Şekil 4.1). 


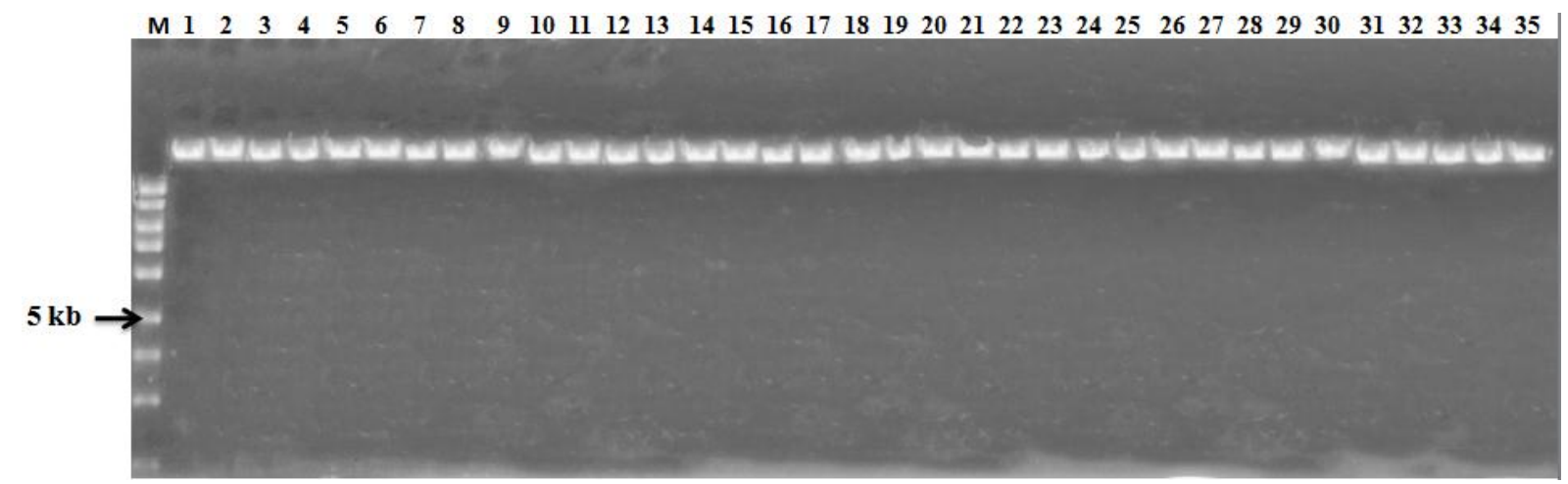

Şekil 4.1. Genomik DNA'ların jel görüntüsü ( \%1'lik Agaroz Jel; M: 1 kb )

\subsubsection{DNA miktar tayini}

Elde edilen genomik DNA'ların konsantrasyonu Nanodrop cihazında bölüm 2.4.3'de belirtildiği gibi $260 \mathrm{~nm}$ dalga boyunda ölçülmüş ve PCR şartlarına en uygun konsantrasyona ayarlanmıştır.

\subsubsection{Belirlenen genlerin seçilen genotiplerle taranması}

Tasarlanan primerlere uygun olan gen bölgelerine uygulanan PCR ile çoğaltılmış ve jel analizi sonucunda 100 bp'lik markör seviyesinde herbir gene ait uzunluklardan (Tablo 4.2) daha büyük bantlar meydana geldiği gözlenmiş̧ir.

Selüloz çok sayıda multimerik selüloz sentaz (CesA) kompleksleriyle sentezlenip, plazma membranında kortikal mikrotübül boyunca iletilmektedir. Bu komplekslerin sadece bilinen bileşenleri, selüloz sentaz proteinleridir [64]. Genotiplerin GhCESA geniyle taranmasının neticesinde (Şekil 4.2) polimorfik bantlar bulunmuştur. 1-10 arasındaki genotipler G. barbadense türüne ait olup bunlar fenotipleme neticesinde uzun ve kaliteli liflere sahip olmasına karşın 1, 3, 5, 7 ve 9. sıradaki genotiplerin genetik bakımdan G. hirsutum'a benzer özellik gösterdiği belirlenmiştir. 10-26 arasındakiler G. hirsutum türüne ait olup fenotipik olarak orta kalite ve orta uzunlukta lif üretmekte ve genetiksel olarak ta aralarında farklılık görülmemiştir. Bununla birlikte, 26- 35 arasındaki genotipler ise yabani tip pamuklardır. Bunlar da ise 27, 28, 29, 30 ve 35. geotiplerde G.hirsutum özelliği gözlenirken diğerleri genetiksel açıdan $G$. barbadense özelliği göstermektedir. Bu sonuçlar neticesin de ise 500-510 bp uzunluğundaki allellerin lif uzaması açısından önemli olabileceği yargısına varılmıştır. Çalışma, 2, 4, 6 ve 8 numaralı genotiplerin ve G. hirsutum türüne ait genotiplerin sekanslarının karşılaş̧ııılmasıyla daha da netleşecektir.

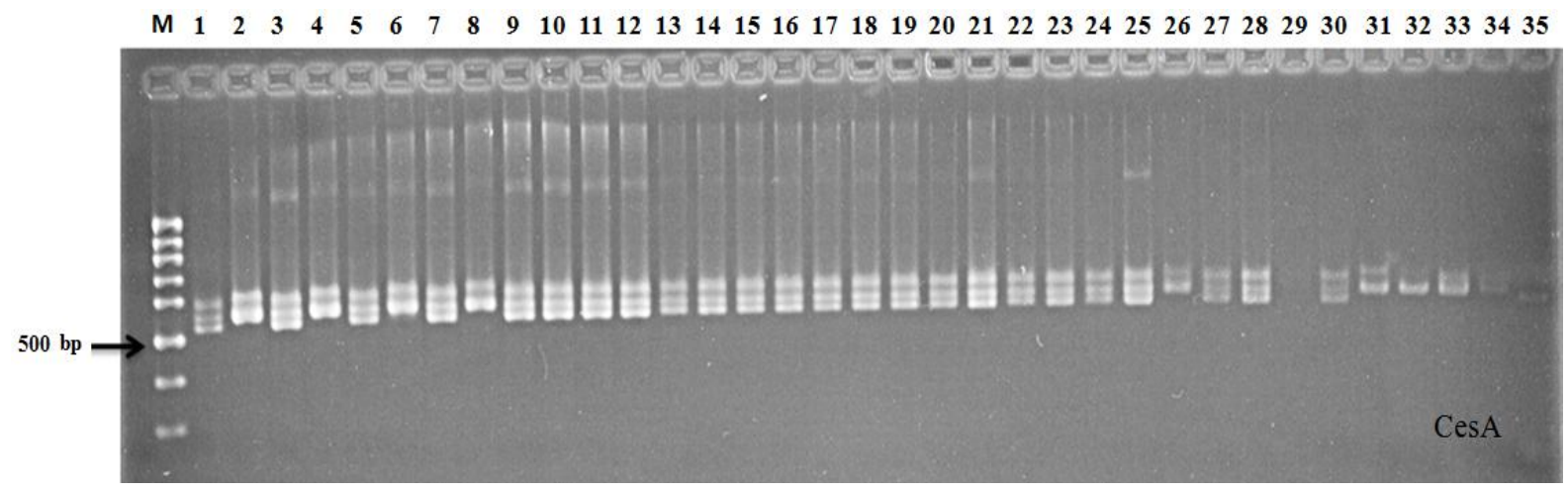

Şekil 4.2. CesA primeriyle taranan 35 genotipin jel görüntüsü

Diğer taraftan lif uzamasıyla etkili diğer genlere bakacak olursak; 
GhEF1A (elongation factor 1A-1,2,4,5 ve 9) uzama faktörünün translasyonunda işlev görmektedir (Xu ve ark.,2007).

GhEF1A genin 35 genotip üzerinde taranmasının neticesinde (Şekil 4.3) 1, 5, 8, 10, 29, 30, 31, 32, 33, 34 ve 35. genotiplerin diğerlerinden farklı bir sonuç gösterdiği gözlenmiştir. Bu genotiplerde diğerlerinden farklı olarak, yaklaşık 500 bp uzunluğundaki bantlar bulunmamaktadır. Bunun neticesinde de 500 bp uzunluğunda çıkan allellerin bulunması halinde çeşitlerin lif uzunluğunu olumsuz yönde etkileyebileceği sonucuna varılmıştır.

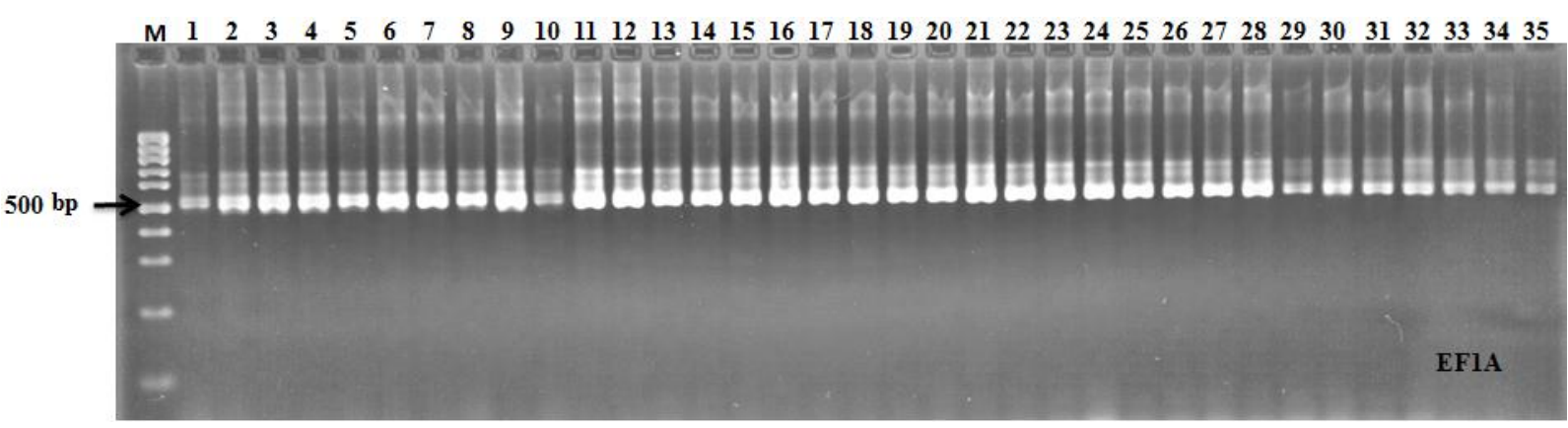

Şekil 4.3. EF1A primeriyle taranan 35 genotipin jel görüntüsü

Pamukta sükroz sentezi (SuS) pamuk lilflerinin gelişiminde önemli bir rol oynamaktadır (Ruan ve ark., 2008). Buna göre; (a) tohum oluşumunun başlaması sırasında sakkaroz kullanımında (b) trikom farklılaşmasında ve (c) hücre duvarı biyosentezi ile lif uzamasını hızlandırmada etkili olmaktadır [65].

SuSy geninde ise sonuçlara baktığımızda genotiplerde farklı amplifikasyonlar görülmektedir. Bu farklılıkların fenotipe ne gibi etkileri olduğu tespit edilememiştir(Şekil 4.4).

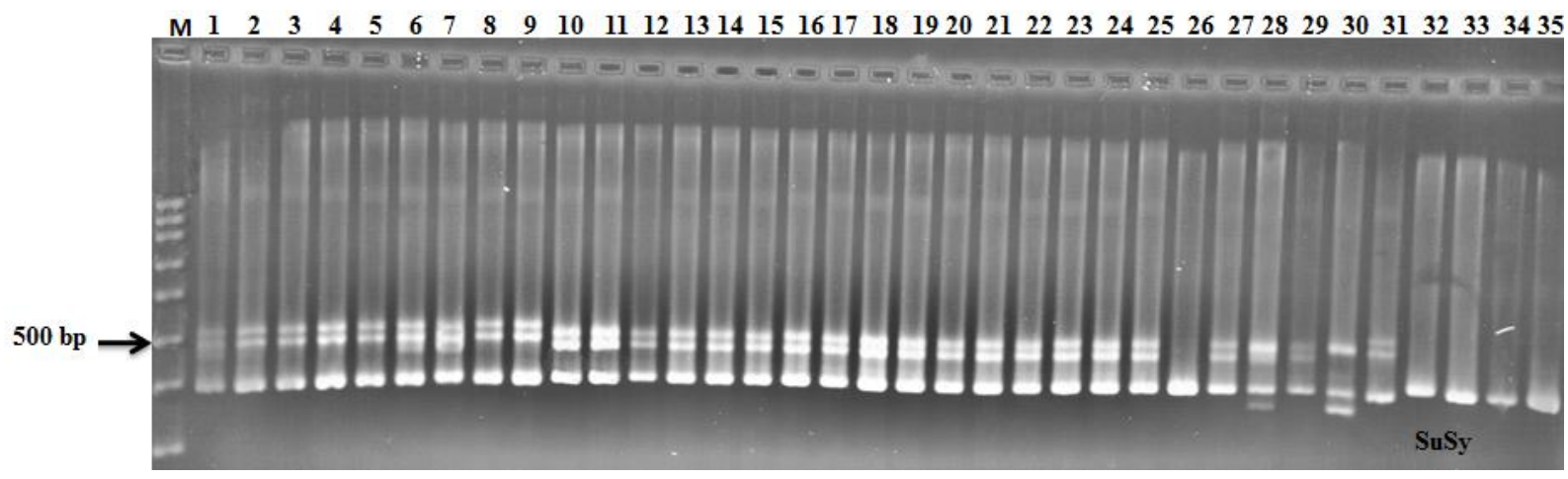

Şekil 4.4. SuSy primeriyle taranan 35 genotipin jel görüntüsü

GhACT1 geni aktin sitoiskeleton ağını düzenlemekte ve bundan dolayı lif uzamasında etkindir. Ancak GhACT1 geninin RNA ile birlikte oluşturduğu yapı liflerdeki aktin sitoiskeleton ağını bozmakta, protein ve mRNA düzeyini önemli ölçüde azaltmaktadır. Aktin ağının bozulması lif uzamasını engellemektedir [59].

GhACT geninin jel görüntüsü dikkate alındığında (Şekil 4.5) bütün genotiplerde benzer alleller olarak bulunduğu gözlenmiştir. Ancak lifsiz olan çeşitlerde de GhACT1 geninin iyi ve orta kalitede lif üreten çeşitlerdekiyle aynı allelleri vermesi, Li ve ark. [59] makalesindeki GhACT1 geninin RNA ile birlikte oluşturduğu yapının aktin ağını bozduğu ve bunun neticesinde de liflerde uzama olayının gerçekleşmediği sonucuna varılmıştır. 


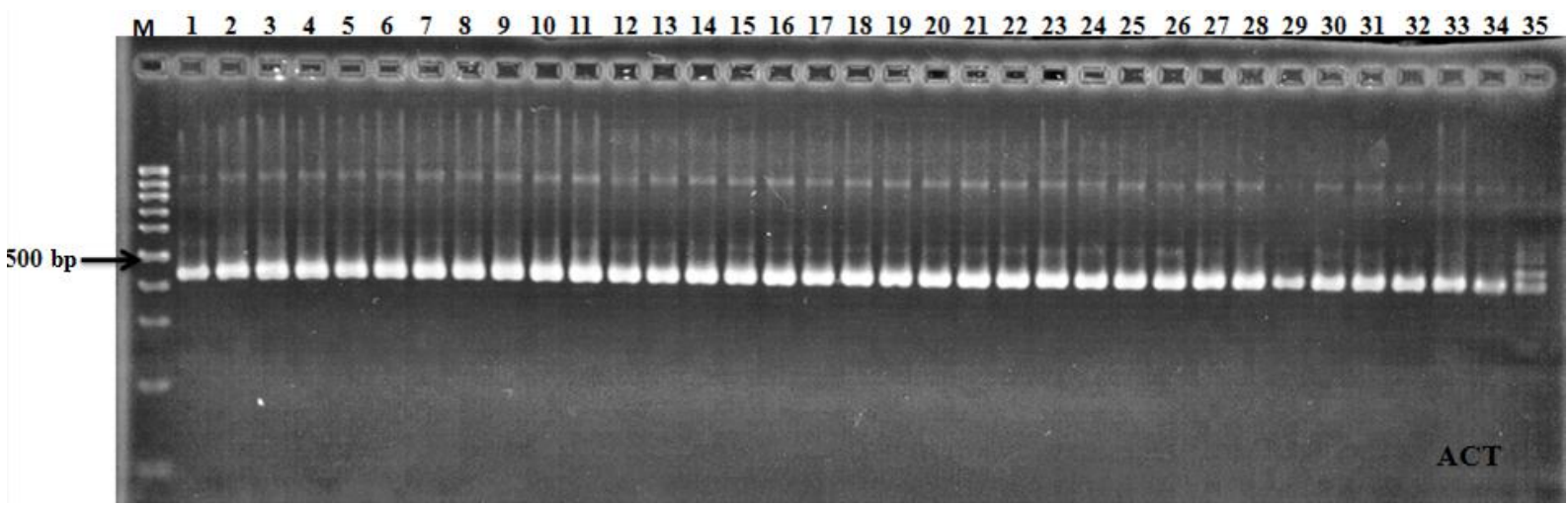

Şekil 4.5. ACT primeriyle taranan 35 genotipin jel görüntüsü

\subsubsection{Genotip ve fenotip iliş kisi}

Belirlenen 35 genotipin CesA primeriyle taranmasiyla yapilan okumalar ve bu genotiplere ait lif uzunluklarının elde edilen bantlarla korelasyonları incelendiğinde, CesA1 ile lif uzunluğu arasında $(r=0,49)$ pozitif ve önemli bir ilişki bulunmaktadır. CesA1 mevcut iken lif uzunluğu da önemli ölçüde artış göstermektedir. CesA2 ile lif uzunluğu arasında $(r=-0,49)$ negatif ve önemli bir sonuç bulunmaktadır. Yani CesA2 mevcut iken lif uzunluğu önemli ölçüde azalma göstermektedir. SuSy ile lif uzunluğu arasında $(r=0,88)$ pozitif ve çok önemli bir ilişki bulunup, SuSy mevcut iken lif uzunluğu da buna bağlı olarak çok önemli düzeyde artı̧̧ göstermektedir (Tablo 4.3).

Tablo 4.3. Lif uzunluğu ile amplifikasyonda farkl11lk gösteren genlerin korelasyonu

\begin{tabular}{|c|l|l|l|}
\hline & esA1 & esA2 & uSy \\
\hline $\begin{array}{c}\text { Lif } \\
\text { Uzunluğu }\end{array}$ & .49 & 0.49 & .88 \\
\hline $\begin{array}{c}\text { Önem } \\
\text { Derecesi (p) }\end{array}$ & .0204 & .0204 & .0001 \\
\hline
\end{tabular}

Korelasyon analizinde kullanılan ve önem seviyelerini etkileyen bantlar Şekil 4.6 ve Şekil 4.7'de detaylı olarak gösterilmiştir.

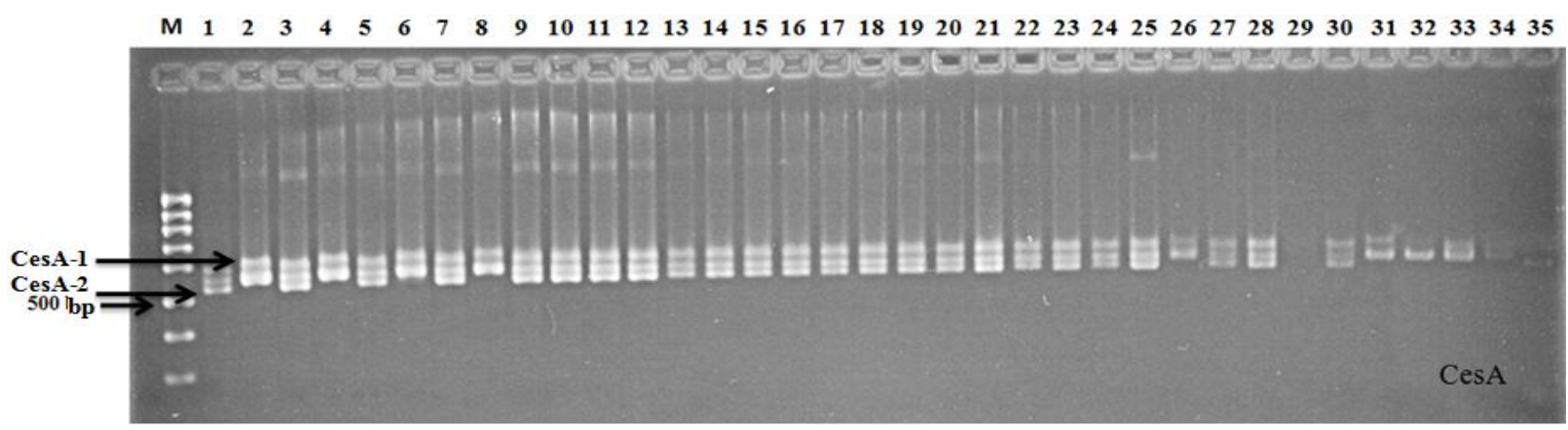

Şekil 4.6. Korelasyon analizinde kullanılan CesA primeri ve ilgili bantların gösterimi 


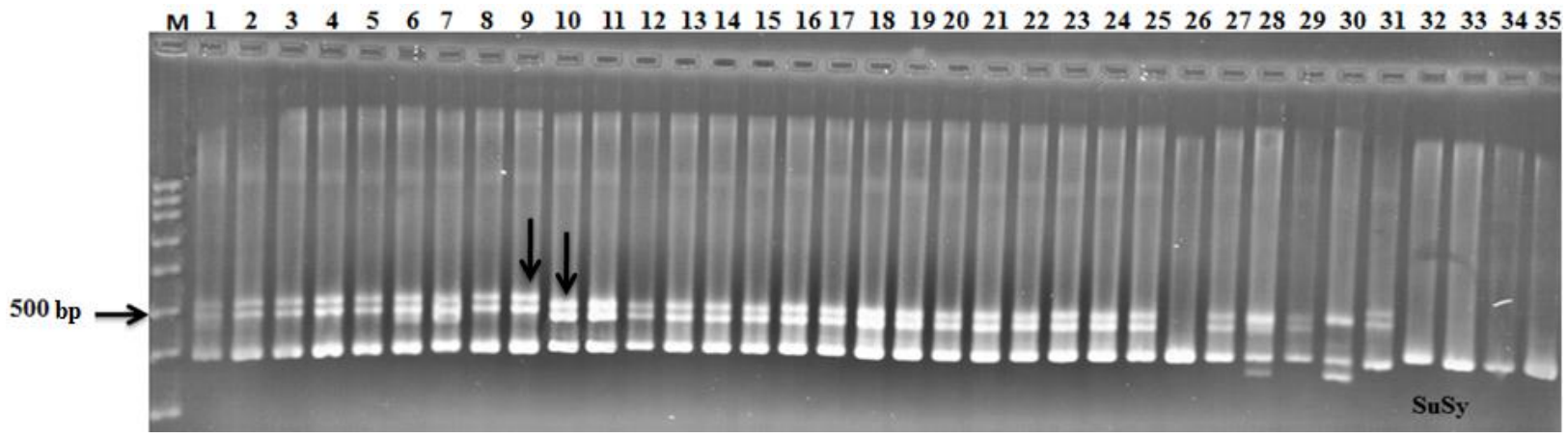

Şekil 4.7. Korelasyon analizinde kullanılan SuSy primeri ve ilgili bantların gösterimi

Bunula birlikte, lif uzunluğuyla CesA geni polimorfizminin ilişkilendirilmesi Şekil 4.8'de verilmiştir. Sütunların en altında bulunan ve 500 bp’ye yakın allelin lif uzunluklarına göre değişimi türlere göre farklılık göstermektedir.

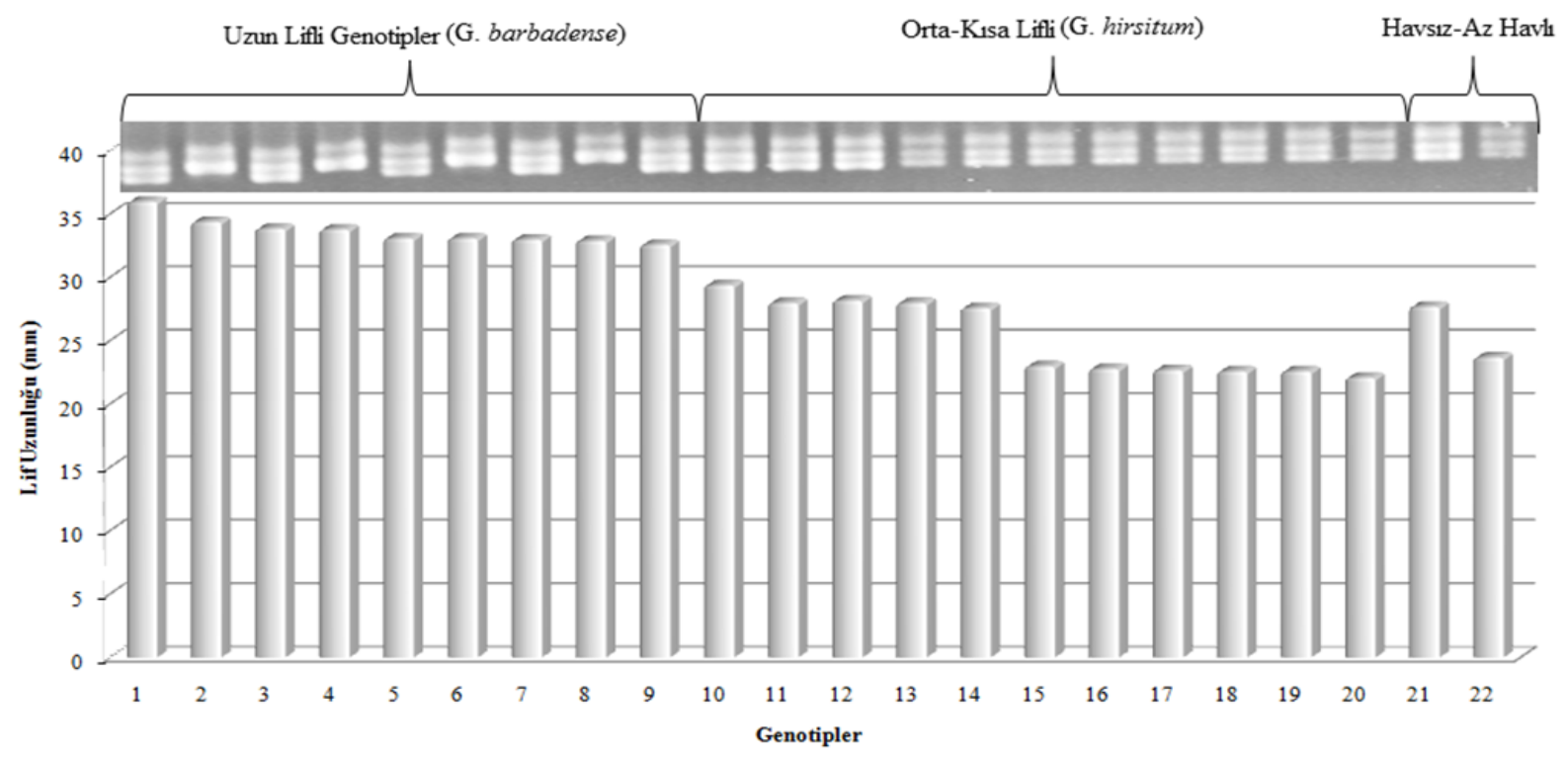

Şekil 4.8. Lif uzunluğu ve CesA polimorfizminin ilişkilendirilmesi

\subsubsection{Bantların jelden kesimi, temizlenmesi ve tek banda indirgenmesi}

Elde edilen jel görüntüleri incelendiğinde, iş yoğunluğu ve zaman kısıtlaması da dikkate alınarak, 4 gen üzerinde yapılan analizlere tek genle devam edilmiş ve ayrıca kullanılan genotip sayısı kademeli olarak azaltılmıştır. İlk olarak farklı gruplardan (genom durumu, tür ve lif özelliklerine göre) toplam 19 genotip seçilerek agaroz jelde koşturulmuştur (Şekil 4.9-A).

Daha sonra, 19 genotip arasından tüm örnekler arasından benzerlik bakımından gruplandırılma yapılarak her bir grubu temsil edebilecek 1 genotip belirlenmiş ve sekanlama işleminde kullanılmak amacıyla bu genotiplere ait her bir bant ayrı bir numune haline getirilmiştir (Şekil 4.9-B).

Jel üzerinde verilen 1 numaralı örnekten kesme işlemiyle herbir bant ayrı ayrı elde edilip PCR'la çoğaltıldıktan sonra \%3'lük agaroz jelde koşturulmuş ve şekil 4.9-B'deki görüntü elde edilmiştir. Bantlarımızın tek olup olmadığını ve sekanslama için gerekli olan yoğunluğa sahip olduğundan emin olunduktan sonra sekanslama işlemine geçilmiştir. 


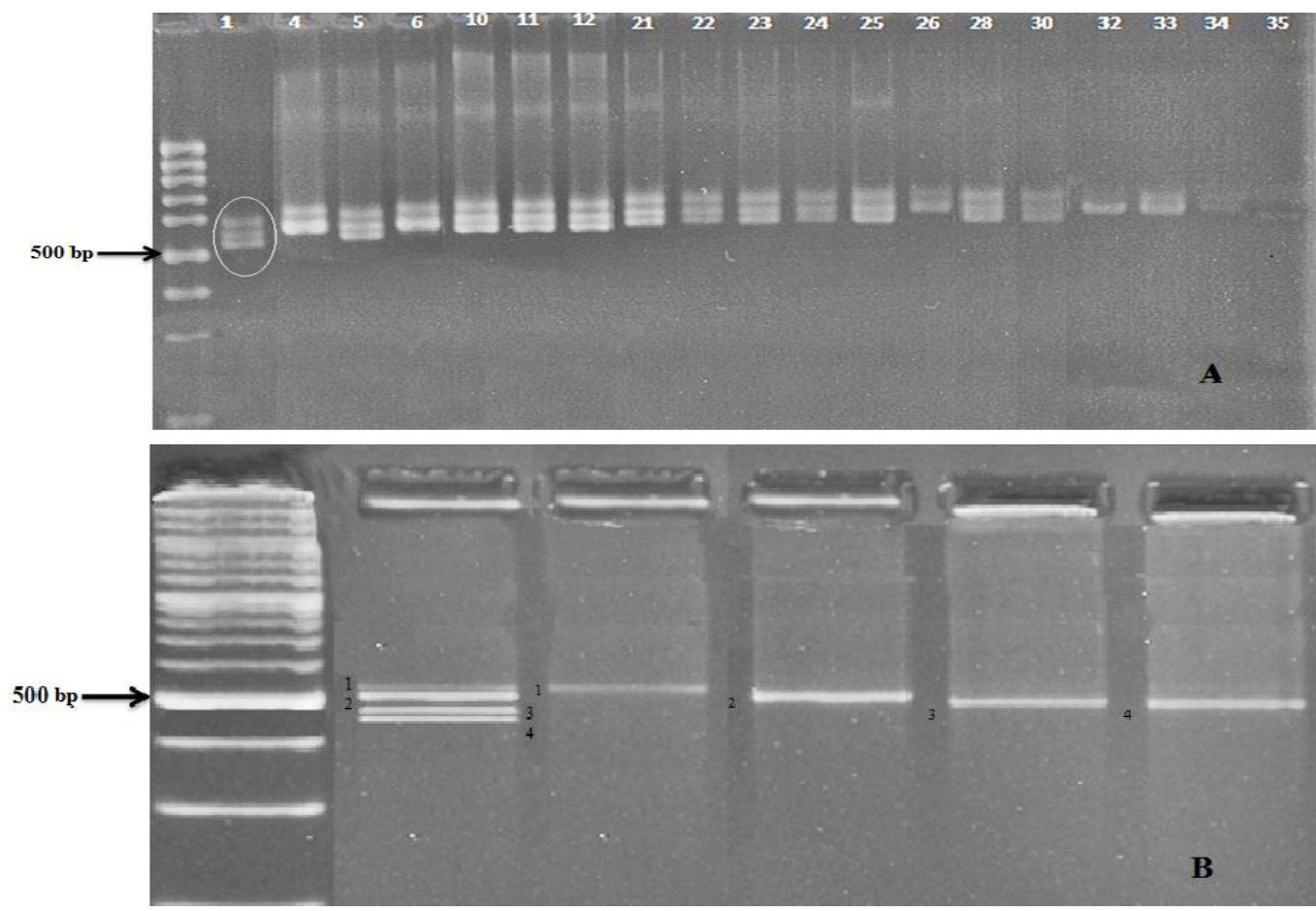

Şekil 4.9. Seçilen 19 genotip ve bunlardan 1. örneğe ait kesilmiş bant görüntüsü

Her bir bant sekanslandıktan sonra elde edilen bantların sekans uzunlukları ve baz çiftleri arasındaki farklılığ1 görmek için sekanslar karşılaştırılmıştır. Baz dizilimleri arasında farklılığın görülmesi üzerine bu sekansların amino asit dizilimleri karşılaştırılmış ve baz farklılıklarının amino asit dizilimini değiştirip değiştirmediği incelenmiştir. İnceleme sonucunda hem jel görüntüsü üzerinde hem de korelasyon analizinde önemli farklılık gösteren 4. bantın amino asitlerinin CesA sekansına ait amino asitlerden farklı olduğu gözlenmiştir (Tablo 4.4). Bu farklılıklar 3 ayrı SNP noktası şeklinde olup, ilk farklılık 328. baz olan Guanin'in adenin'e dönüşmesi şeklinde olup, aminoasit sentezinde farklıllğa yol açmadığı belirlenmiştir. Diğer SNP noktasında 343. baz olan Timin'in Sitozin'e dönüşmesiyle Lizin (L) amino asitinin Serin'e (S) dönüşmesini sağladığı ve son olarak görülen SNP'nin ise 397. baz olan Adenin'in Guanin'e dönüşmesiyle Histidin (H) aminoasitinin Arjinin'e (A) dönüşmesini sağlamıştır. Ancak, diğer bantların aminoasit karşılaş̧ırmaları dikkate alındığında sadece 2. bantın ortak baz dizindeki 28. bazı olan Guanin'in Timin'e dönüşmesiyle Glisin (G) amino asitinin Valin'e (V) dönüştüğü gözlenmiştir. Hem 2. bantdaki SNP hem de 4. banta ait SNP'lerin amino asit değişimlerinin fenotip üzerine ne şekilde etki ettiğinin daha iyi anlaşılabilmesi için farklı olduğu düşünülen $G$. barbadense ve G. hirsutum türlerine ait genotiplerde sekanslama ve karşılaştırma uygulamalarının yapılması gerekmektedir.

Glisin, hücre uzaması sürecinde etkin rol almaktadır. Mangeon ve ark. [66] çalışmalarında, A. thaliana bitkisinde glisin sentezinde rol alan genler üzerine çalışmışlar ve glisinin hücre uzamasında direkt veya indirekt olarak etkili olduğunu, glisin sentezini sağlayan genlerin mutant ve transgenik bitkilerde normal bitkilere nazaran daha az ifade edildiğini belirlemişlerdir.

Lözin hücre proliferasyonu, kök hücre bakımı, hormon algılama gibi gelişimsel ve simbiyotik yaşamda ve yaralanmalara özel veya özel olmayan cevaplar gibi savunma ile ilgili süreçlerde etkilidir [67]. 
Serin, kloroplast, sitosol ve mitokondriye bağlı olarak sülfat asimilasyonunu ve azaltma yollarında etki göstermektedir [68]. Serin metabolizmada, pürinler, pirimidinler, sistein, triptofan (bakterilerde) ve daha birçok metabolitin biyosentezinde önemli bir role sahiptir [69].

Histidin, dokuları geliştirmeye ve korumaya yardımcı olmaktadır [70].

Arjinin nitrit oksit oluşumunda etkilidir ve böylelikle de patojen infeksiyonlara karşı savunmada, sinyalizasyon ve sinyal iletimini sağlamaktadır. Kotiledon ve tohumlardaki amino asitlerde fazla miktarda bulunmakta ve tohumlarda nitrojen birikiminde etkin bir rol oynamaktadır [71].

Tablo 4.4. Sekanslanan bantlardaki amino asit dizilimlerinin orijinal sekansla karşılaştırılmas1
\begin{tabular}{|l|r|r|}
\hline & Amino asit değişimi & Nükleotid değişimi (yeri) \\
\hline . Bant & - & $\mathrm{A} \rightarrow \mathrm{G}(352)$ \\
\hline . Bant & $\mathrm{G} \rightarrow \mathrm{V}$ & $\mathrm{G} \rightarrow \mathrm{T}(28)$ \\
\hline . Bant & - & $\mathrm{A} \rightarrow \mathrm{T}(29)$ \\
\hline . Bant & - & $\mathrm{A} \rightarrow \mathrm{G}(139)$ \\
\hline . Bant & - & $\mathrm{G} \rightarrow \mathrm{A}(328)$ \\
\hline . Bant & $\mathrm{L} \rightarrow \mathrm{S}$ & $\mathrm{T} \rightarrow \mathrm{C}(343)$ \\
\hline . Bant & $\mathrm{H} \rightarrow \mathrm{A}$ & $\mathrm{A} \rightarrow \mathrm{G}(397)$ \\
\hline
\end{tabular}

Bu çalışmada, elde edilen sekanslarda ise;

Glisin'in $\rightarrow$ Valin'e, Lözin'in $\rightarrow$ Serin'e ve Histidin'in $\rightarrow$ Arjinin'e değişimi lif kalitesine etkili olabilir. Ancak araştırmanın doğruluğu daha detaylı çalışmayla ortaya konabilecektir.

\section{Sonuç ve Tartışma}

Seçilen genotiplere ilişkin lif uzunlukları 0-36 mm arasında değişmiştir.

G.barbadense L. genotipleri daha kaliteli lif üretmiş olup, G.hirsutum L. genotipleri orta derecede kaliteli lifler üretmişlerdir.

CesA geni, seçilen genotipler arasında daha fazla polimorfizm oluşturmuştur.

Yaklaşık olarak 500-510 bp uzunluğundaki allellerin SNP taşıdığı ve 2 allelde bulunan SNP'lerin amino asit değişimine neden olduğu belirlenmiştir. Bu değişimlerin lif kalitesiyle ilişkili olabileceği ve daha detaylı çalışmaların yapılması gerektiği sonucuna varılmıştır.

\section{Kaynaklar}

[1] Jia S.R., 'Transgenic Cotton' Science Press, Beijing/New York, 2005.

[2] Qin Y., Zhu Y., 'A brief summary of major advances in cotton functional genomics and molecular breeding studies in china' Chinese Science Bulletin, Vol.52, No.23, 3174-3178, 2007. 
[3] John M.E., Crown L.J., 'gene expression in cotton (Gossypium hirsutum L.) Fiber: Cloning of the mrnas’ Proc Natl Acad Scienc., Usa 89: 5769-5773, 1992.

[4] Tokumoto H., Wakabayashi K., Kamisaka S., Hoson T., 'Changes in the sugar composition and molecular mass distribution of matrix polysaccharides during cotton fiber development' Plant Cell Physiol., 43(4):411-418, 2002.

[5] Lee J.J.,Woodward, A.W. Chen Z.J., 'Gene expression changes and early events in cottton fibre development' Annals of Botany, 100:1391-1401, 2007.

[6] Basra A., Malik C.P., 'Development of the Cotton Fiber' International Review of Cytology 89: 65-113, 1984.

[7] Paterson A.H., Saranga Y., Menz M., Jiang C.X., Wright R.J., 'QTL analysis of genotype-environment interactions affecting cotton fiber quality’ Theor Appl Genetics. 106: 384-396. 2003.

[8] Hulskamp M., 'Plant trichomes: A model for cell differentiation' Nature Reviews. Molecular Cell Biology 5: 471-480, 2004.

[9] Hulskamp, M., Misera, S., Jurgens, G., 'Genetic dissection of trichome cell development in Arabidopsis' Cell, 76: 555-566, 1994.

[10] Hulskamp M., Schnittger A.T., 'Spatial regulation of trichome formation in Arabidopsis thaliana' Seminars in Cell and Developmental Biology, 9: 213-220, 1998.

[11] Marks Md., 'Molecular genetic analysis of trichome development in Arabidopsis' Annual Review of Plant Physiology and Plant Molecular Biology, 48: 137-163, 1997.

[12] Dubois, F., Brugie, R.N., Sangwan, R.S., Hirel, B., 'localization of tobacco cytosolic glutamine synthetase enzymes and the corresponding transcripts shows organ- and cell-specific patterns of protein synthesis and gene expression’ Plant Molecular Biology, 31, 803-817, 1996.

[13] Ochs, G., Schock, G., Trischler, M., Kosemund, K., Wild, A., 'complexity and expression of the glutamine synthetase multigene family in the amphidiploid crop Brassica napus' Plant Molecular Biology, 39, 395-405, 1999.

[14] Yajun, H., Wangzhen, G., Xinlian, S., Tianzhen, Z., 'molecular cloning and characterization of a cytosolic glutamine synthetase gene, a fiber strength-associated gene in cotton' Planta, 228:473-483, 2008.

[15] Ming, L., Zhong-Yi, X., Yue-Hua, X., Xian-Bi, L., Jian-Ping, Z., Ming-Yu, H., Yan, P., 'Cloning and expression analysis of a brassinosteroid biosynthetic enzyme gene, GhDWF1, from cotton (Gossypium hirsufurm L.)’ Agricultural Sciences in China, 6(11): 1297-1305, 2007.

[16] Suo, J., Liang, X., Pu, L., Zhang, Y., Xue, Y., 'Identification of GhMYB109 encoding a R2R3 MYB transcription factor that expressed specifically in fiber initials and elongating fibers of cotton (Gossypium hirsutum L.)' Biochim. Biophys. Acta, 1630: 25-34, 2003.

[17] Preuss, M., Kovar, D., Lee, Y., Staiger, C., Delmer, D., Liu, B., 'A plant-specific kinesin binds to actin microfilaments and interacts with cortical microtubules in cotton fibers' Plant Physiol, 136:3945-3955, 2004.

[18] Xu, T., Qu, Z., Yang, X., Qin, X., Xiong, J., Wang, Y., Ren, D., Liu, G., 'A cotton kinesin GhKCH2 interacts with both microtubules and microfilaments' Biochem J. doi,10.1042/BJ20082020, 2009. 
[19] Notle, K.D., Hendrix, D.L., Radin, J.W., Koch, K.E., 'sucrose synthase localization during initiation of seed development and trichome differentiation in cotton ovules' Plant Physiol, 109: 1285-1293, 1995.

[20] Zhu, Y.Q., Xu, K.X., Luo, B.,Wang, J.W., Chen, X.Y., 'An ATP-Binding cassette transporter GhWBC1 from elongating cotton fibers' Plant Physiology, Vol. 133, Pp. 580-588, 2003.

[21] Kim, H.J., Triplett, B.A., 'Characterization of GhRac1 GTPase expressed in developing cotton (Gossypium hirsutum L.) fibers’ Biochimica Et Biophysica Acta., 1679: 214-221, 2004.

[22] Richmond, T., Somerville, C., 'The cellulose synthase superfamily' Plant Physiology, 124, 495-498, 2000.

[23] Richmond, T., Somerville, C., 'Integrative approaches to determining Csl function' Plant Molecular Biology, Reporter 47, 131-143, 2001

[24] Desprez, T., Vernhettes, S., Fagard, M., Refregier, G., Desnos, T., Aletti, E., Py, N., Pelletier, S., Hofte, H., 'Resistance against herbicide isoxaben and cellulose deficiency caused by distinct mutations in same cellulose synthase 1soform CESA6’ Plant Physiology, 128, 482-490, 2002.

[25] Doblin, Ms., Kurek, I., Jacob-Wilk, D., Delmer, Dp., 'Cellulose biosynthesis in plants: from genes to rosettes' Plant and Cell Physiology, 43, 1407-1420, 2002.

[26] Robert, S., Mouille, G., Hofte, H., 'The mechanism and regulation of cellulose synthesis in primary walls: lessons from cellulose-deficient Arabidopsis mutants' Cellulose 11, 351-364, 2004.

[27] Scheible, W., Eshed, R., Richmond, T., Delmer, D., Somerville, C., 'Modifications of cellulose synthase confer resistance to isoxaben and thiazolidinone herbicides in Arabidopsis Ixr1 mutants' Proceedings of the National Academy of Sciences, USA 98, 10079-10084, 2001.

[28] Taylor, N., Laurie, S., Turner, S., 'Multiple cellulose synthase catalytic subunits are required for cellulose synthesis in Arabidopsis’ The Plant Cell, 12, 2529-2540, 2000.

[29] Taylor, N., Howells, R., Huttly, A., Vichers, K., Turner, S., 'Interactions among three distinct CesA proteins essential for cellulose synthesis' Proceedings of the National Academy of Sciences, USA 100, $1450-1455,2003$.

[30] Desprez, T., Juraniec, M., Crowell, E., Jouy, H., Pochylova, Z., Parcy, F., Hofte, H., Gonneau, M., Vernhettes, S., 'Organization of cellulose synthase complexes involved in primary cell wall synthesis in Arabidopsis thaliana' Proceedings of the National Academy of Sciences, USA 39, 15572-15577, 2007.

[31] Persson, S., Paredez, A., Carroll, A., Palsdottir, H., Doblin, M., Poindexter, P., Khitrov, N., Auer, M., Somerville, C., 'Genetic evidence for three unique components in primary cell-wall cellulose synthase complexes in Arabidopsis' Proceedings of the National Academy of Sciences, USA 39, 15566$15571,2007$.

[32] Lacape, J.M., Nguyen, T.B., Thibivilliers, S., Bojinov, B., Courtois, B., Cantrell, R.G., 'A combined RFLP-SSR-AFLP map of tetraploid cotton based on a Gossypium hirsutum $\times$ Gossypium barbadense backcross population’ Genome, 46:612-626, 2003.

[33] Mei, M., Syed, N.H., Gao, W., Thaxton, P.M., Smith C.W., 'Genetic mapping and QTL analysis of fiber-related traits in cotton (Gossypium)' Theor. Appl. Genet., 108: 280-291, 2004.

[34] Zhang, T., Yuan, Y., Yu, J., Guo, W., Kohel, R.J., 'Molecular tagging of a major QTL for fiber strength in upland cotton and 1ts marker-assisted selection' Theor. Appl. Genet., 106:262-268, 2003. 
[35] Rong, J., Abbey, C., Bowers, J.E., Brubaker, C.L., Chang, C., Chee, P.W., 'A 3347-locus genetic recombination map of sequence-tagged sites reveals features of genome organization, transmission and evolution of cotton (Gossypium)' Genetics, 166:389-417, 2004.

[36] Nguyen, T.B., Giband, M., Brottier, P., Risterucci, A.M., Lacape, J.M., 'Wide coverage of the tetraploid cotton genome using newly developed microsatellite markers' Theor. Appl. Genet., 109:167$175,2004$.

[37] Han, Z., Guo, W., Song, X., Zhang, T., 'Genetic mapping of EST-Derived microsatellites from the diploid Gossypium arboreum in allotetraploid cotton' Mol. Genet. Genomics, 272(3):308-327, 2004.

[38] Han, Z., Wang, C., Song, X., Guo, W., Gou, J., Li, C., 'Characteristics, development and mapping of Gossypium hirsutum derived EST-SSRs in allotetraploid cotton' Theor. Appl. Genet. 112:430-439, 2006.

[39] Guo, W., Cai, C., Wang, C., Han, Z., Song, X., Wang, K., Niu, X., Wang, C., Lu, K., Shi, B., Zhang, T., 'A microsatellite-based, gene-rich linkage map reveals genome structure, function and evolution in Gossypium' Genetics 176: 527-541, 2007.

[40] Yu, J., Yu, S., Lu, C., Wang, W., Fan, S., Song, M., Lin, Z., Zhang, X., Zhang, J., 'high-density linkage map of cultivated allotetraploid cotton based on SSR, TRAP, SRAP and AFLP markers' J. Integr. Plant Biol., 49(5): 716-724, 2007.

[41] Wu, J., Gutierrez, O.A., Jenkis, J.N., Mccarty, J.C., Zhu, J., 'Quantitative analysis and QTL mapping for agronomic and fiber traits in and R1 population of upland cotton' Euphytica 165:213-245, 2009.

[42] Lin, Z., He, D., Zhang, X., Nie, Y., Guo, X., Feng, C., 'Linkage map construction and mapping QTL for cotton fibre quality using SRAP, SSR and RAPD’ Plant Breed., 124:180-187, 2005.

[43] Jiang, C., Wright, R.J., El-Zik, K.M., Paterson, A.H., 'Polyploid formation created unique avenues for response to selection in Gossypium (Cotton)' Proc. Natl. Acad. Sci., Usa 95: 4419-4424, 1998.

[44] Shappley, Z.W., Jenkins, J.N., Meredith, W.R., Mccarty, J.C., 'An RFLP linkage map of upland cotton (Gossypium Hirsutum L.)’ Theor. Appl. Genet., 97: 756-761, 1998.

[45] Ulloa, M., Meredith, W.R., 'Genetic linkage map and QTL analysis of agronomic and fiber traits in an intraspecific population' J. Cotton Sci., 4: 161-170, 2000.

[46] Kohel, R.J., Yu, J., Park, Y.H., Lazo, G.R., 'Molecular mapping and characterization of traits controlling fiber quality in cotton' Euphytica, 121:163-172, 2001.

[47] Ulloa, M., Meredith, W.R., Shappley, Z.W., Kahler, A.L., 'RFLP genetic linkage maps from four F2.3 populations and a joinmap of Gossypium hirsutum L.' Theor. Appl. Genet., 104:200-208, 2002.

[48] Zhang, T., Yuan, Y., Yu, J., Guo, W., Kohel, R.J., 'Molecular tagging of a major QTL for fiber strength in upland cotton and its marker-assisted selection' Theor. Appl. Genet., 106:262-268, 2003.

[49] Zhang, Z., Xiao, Y., Luo, M., Li, X., Luo, X., Hou, L., 'Construction of a genetic linkage map and QTL analysis of fiber-related traits in upland cotton (Gossypium hirsutum L.)' Euphytica, 144(1):91-99, 2005.

[50] Li, X. B., Fan, X. P., Wang, X. L., 'The Cotton ACTIN1 gene is functionally expressed in fibers and participates in fiber elongation' Plant Cell, 17: 859-875, 2005. 
[51] Park, Y.H., Alabady, M.S., Ulloa, M., Sickler, B., Wilkins, T.A., Yu, J., 'Genetic mapping of new cotton fiber loci using EST-derived microsatellites in an interspecific recombinant inbred line cotton population' Mol. Genet. Genomics, 274:428-441, 2005.

[52] Shen, X., Guo, W., Zhu, X., Yuan, Y., Yu, J., Kohel, R., 'Molecular mapping of QTLs for fiber qualities in three diverse lines in upland cotton using SSR markers' Mol. Breed., 15: 169-181, 2005.

[53] Shen, X., Zhang, T., Guo, W., Zhu, X., Zhang, X., 'Mapping fiber and yield QTLs with main, epistatic, and QTL $\times$ Environment interaction effects in recombinant inbred lines of upland cotton' Crop Sci., 61-66, 2006.

[54] Frelichowski, J.M., Palmer, M.B., Main, D., Tomkins, J.P., Cantrell, R.G., Stelly, D.M., 'Cotton genome mapping with new microsatellites from Acala 'Maxxa' Bac-Ends' Mol. Genet. Genomics, 275:479-491, 2006.

[55] Yu, J., Yu, S., Lu, C., Wang, W., Fan, S., Song, M., Lin, Z., Zhang, X., Zhang, J., 'High-density linkage map of cultivated allotetraploid cotton based on SSR, TRAP, SRAP and AFLP markers' $J$. Integr. Plant Biol., 49(5): 716-724, 2007.

[56] Wu, J., Gutierrez, O.A., Jenkis, J.N., Mccarty, J.C., Zhu, J., 'Quantitative analysis and QTL mapping for agronomic and fiber traits in and R1 population of upland cotton' Euphytica 165:213-245, 2009.

[57] Thompson, J.D., Gibson, T.J., Plewniak, F., Jeanmougin, F., Higgins, Dg., 'The clustalx windows interface: Flexible strategies for multiple sequence alignment aided by quality analysis tools' Nucleic Acids Res;24: 4876-82, 1997.

[58] Sas I. SAS/STAT software: Changes and enhancements through release 6.12. SAS Inst., Cary, NC., 1997.

[59] Li, X. B., Fan, X. P., Wang, X. L., 'The Cotton ACTIN1 gene is functionally expressed in fibers and participates in fiber elongation' Plant Cell, 17: 859-875, 2005.

[60] Li, C.H., Zhu, Y.Q., Meng, Y.L., Wang, J.W., Xu, K.X., Zhang, T.Z., Chen, X.Y., 'Isolation of genes preferentially expressed in cotton fibers by cDNA filter arrays and RT-PZR' Plant Science, 163:1113$1120,2002$.

[61] Betancur, L., Singh, B., Rapp, R. A., Wendel, J.F., Marks, D.M., Roberts, A.W., Haigler, C.H., 'Phylogenetically distinct cellulose synthase genes support secondary wall thickening in Arabidopsis shoot trichomes and cotton fiber' Journal of Integrative Plant Biology, 52 (2): 205-220, 2010.

[62] Lee, J.J., Hassan, O.S.S., Gao, W., Wang, J., Wei, E.N., Russel, J.K., 'Developmental and gene expression analyses of a cotton naked seed mutant' Planta, 223: 418-432, 2006.

[63] Xu, W., Wang, X., Wang, H., Li, X., 'Molecular characterization and expression analysis of nine cotton GhEF1A genes encoding translation elongation factor 1A’ Gene, 389: 27-35, 2007.

[64] Endler, A., Persson, S., 'Cellulose synthases and synthesis in Arabidopsis' Molecular Plant, 199-211, 2011.

[65] Notle, K.D., Hendrix, D.L., Radin, J.W., Koch, K.E., 'Sucrose synthase localization during initiation of seed development and trichome differentiation in cotton ovules' Plant Physiol, 109: 1285-1293, 1995.

[66] Mangeon, A., Junqueira, R.M., Sachetto-Martins, G., 'Functional diversity of the plant glycine-rich proteins superfamily’ Plant Signal Behav., 5(2): 99-104, 2010. 
[67] Torii, K.U., 'Leucine-rich repeat receptor kinases in plants: Structure, function, and signal transduction pathways' International Review of Cytology, 234/1-46, 2004.

[68] Droux, M., 'Plant serine acetyltransferase: New insights for regulation of sulphur metabolism in plant cells’ Plant Physiology and Biochemistry, 41: 619-627, 2003.

[69] Gulledge, J.B., Aggen, H.B., Huang, A.C., Chamberlin, N.-A.R., 'The Microcystins and nodularins: Cyclic polypeptide inhibitors of PP1 and PP2A’Curr Med Chem. 9(22):1991-2003.

[70] Ashenberg, O., Rozen-Gagnon, K., Laub, M.T., Keating, A.E., 'Determinants of homodimerization specificity in histidine kinases’ Journal of Molecular Biology, 413/ 222-235, 2011.

[71] Slocum, R.D., 'Genes, enzymes and regulation of arginine biosynthesis in plants' Plant Physiology and Biochemistry, 43/729-745, 2005. 